\title{
Simultaneous Incorporation of Magnesium and Carbonate in Apatite: Effect on Physico-chemical Properties
}

\author{
Marcia S. Sader ${ }^{a *}$, Kanthi Lewis ${ }^{\mathrm{b}}$, Gloria A. Soares $^{\mathrm{a}}$, Racquel Z. LeGeros ${ }^{\mathrm{b}}$ \\ aProgram in Metallurgical and Materials Engineering - PEMM, \\ Alberto Luiz Coimbra Institute for Graduate Studies and Research in Engineering - COPPE, \\ Federal University of Rio de Janeiro - UFRJ, Rio de Janeiro, RJ, Brazil \\ ${ }^{\mathrm{b}}$ Department of Biomaterials and Biomimetics, NYU College of Dentistry, \\ New York University - NYU, New York, NY, USA
}

Received: March 14, 2012; Revised: December 20, 2012

\begin{abstract}
Synthetic apatites are widely used both in the dental and the orthopaedic fields due to their similarity in composition with the inorganic phase of hard tissues. Biologic apatites are not pure hydroxyapatite (HA), but are calcium-deficient apatites with magnesium and carbonate as minor but important substituents. The aim of the present study was to produce a more soluble biomaterial through the simultaneous substitution of magnesium and carbonate in the apatite structure to accelerate the degradation time in the body. The physico-chemical and dissolution properties of unsintered magnesium and carbonate-substituted apatite (MCAp) with similar $\mathrm{Mg} / \mathrm{Ca}$ molar ratio (0.03) and varying $\mathrm{C} / \mathrm{P}$ molar ratio were evaluated. The resultant powders were characterised using several techniques, such as FTIR, TGA, XRD, ICP and SEM, while the release of calcium ions in a pH 6 solution was monitored using a Ca-ion selective electrode. The results showed a decrease of crystallite size and an increase in the release of calcium to the medium as the carbonate content in the samples increased.
\end{abstract}

Keywords: calcium-deficient apatite, ionic substitutions, crystallinity, bone graft

\section{Introduction}

Synthetic apatites and related calcium phosphates are biocompatible, bioactive, and osteoconductive compounds and their similarity in composition to bone and tooth make them the most commonly used ceramics for bone repair in orthopaedics and dentistry ${ }^{1,2}$.

The apatite structure, e.g. hydroxyapatite $\left(\mathrm{Ca}_{10}\left(\mathrm{PO}_{4}\right)_{6}(\mathrm{OH})_{2}\right)$, allows cationic (for $\left.\mathrm{Ca}^{2+}\right)$ and anionic (for $\mathrm{PO}_{4}^{3-}$ and/or $\mathrm{OH}^{-}$groups) substitutions. Such substitutions affect the crystallography (crystal size, lattice parameters), physico-chemical properties (e.g., solubility) and cell and tissue response $\mathrm{e}^{1-6}$.

Magnesium $\left(\mathrm{Mg}^{2+}\right)$ and carbonate $\left(\mathrm{CO}_{3}^{2-}\right)$ are two minor but important elements associated with biological apatites, which have an average concentration of 0.6 wt. (\%) $\mathrm{Mg}^{2+}$ and 7.5 wt. (\%) $\mathrm{CO}_{3}^{2-}$ in the case of bone apatite ${ }^{1,7,8}$.

Magnesium incorporation in apatite lattice is very limited and is directly dependent on $\mathrm{Mg} / \mathrm{Ca}$ molar ratio, temperature, $\mathrm{pH}$ and the presence of carbonate ${ }^{1,7,8}$. Even the limited incorporation of magnesium causes disturbances in the apatite lattice, decreasing its crystallinity and consequently increasing the dissolution rates ${ }^{1,7-11}$.

Carbonate levels in the bone play an important role in the biochemistry of hard tissues ${ }^{3,9}$. The effect of the $\mathrm{CO}_{3}{ }^{2-}$ substitution in the apatite lattice may be directly related to the mechanism of dissolution-precipitation cycles that occur

*e-mail: msader@metalmat.ufrj.br during bone tissue regeneration ${ }^{3}$. Two types of carbonate ion substitutions can occur in two distinct atomic sites in the apatite lattice, and have been described as A- or B-type ${ }^{1}$. The A-type substitution occurs when $\mathrm{CO}_{3}{ }^{2-}$ substitutes for the hydroxyl $\left(\mathrm{OH}^{-}\right)$ions ${ }^{12,13}$, and the B-type substitution occurs when $\mathrm{CO}_{3}{ }^{2-}$ substitutes for the phosphate $\left(\mathrm{PO}_{4}^{3-}\right)$ ions ${ }^{1,14}$.

Depending on the application of the bone graft material, the in vitro solubility is one of the important parameters in the evaluation of their biodegradability and in vivo performance ${ }^{3}$.

The implant degradation rate should occur simultaneously with the formation of new bone matrix by the cells. This can be positive, as regenerative medicine aims to use materials more degradable and resorbable in order to be replaced gradually by the new bone after implantation.

Evaluation of the dissolution-reprecipitation behaviour of the substituted apatites can be monitored by the $\mathrm{Ca}$ and $\mathrm{P}$ ions released with the soaking time in several buffer solutions. Among them, the acetate buffer solution is free of these ions, and its use in acid $\mathrm{pH}$ range try to simulate an inflammatory process and at the same time reduce the tests periods due to an accelerating dissolution reaction ${ }^{5,15}$.

Our aim was to study the effect of the simultaneous incorporation of magnesium and carbonate ions into the apatite lattice on the physico-chemical and dissolution properties of unsintered apatites obtained by aqueous precipitation. 


\section{Experimental Methods}

\subsection{Synthesis of magnesium and carbonate- substituted apatites (MCAp)}

Magnesium carbonate-free apatites (Ap) and magnesium carbonate-substituted apatites (MCAp) with similar $\mathrm{Mg} / \mathrm{Ca}$ molar ratio of 0.03 and different carbonate contents $[\mathrm{A}(3 \mathrm{Mg} / 0 \mathrm{C} / 1 \mathrm{P})$; $\mathrm{B}(3 \mathrm{Mg} / 1 \mathrm{C} / 1 \mathrm{P})$; $\mathrm{C}(3 \mathrm{Mg} / 3 \mathrm{C} / 1 \mathrm{P})$ and $\mathrm{D}(3 \mathrm{Mg} / 5 \mathrm{C} / 1 \mathrm{P})]$ were synthesised by aqueous precipitation. Briefly, a solution containing $0.02 \mathrm{M}$ calcium acetate $\left(\mathrm{CaC}_{4} \mathrm{H}_{6} \mathrm{O}_{4}\right)$ and $0.02 \mathrm{M}$ magnesium acetate $\left(\mathrm{MgC}_{4} \mathrm{H}_{6} \mathrm{O}_{4}\right)$ were added dropwise into a stirring solution containing $0.01 \mathrm{M}$ sodium phosphate (molar ratio $\left.\mathrm{Na}_{2} \mathrm{HPO}_{4} / \mathrm{NaH}_{2} \mathrm{PO}_{4}=1: 1\right)$ solution and different volumes of $0.1 \mathrm{M}$ sodium bicarbonate solution $\left(\mathrm{NaHCO}_{3}\right)$ at $95{ }^{\circ} \mathrm{C}$ and unadjusted $\mathrm{pH}$. The solutions were prepared by using reagent grade chemicals (Merck, Darmstadt, Germany). The powders were digested for $3 \mathrm{~h}$ at the same temperature, filtered, washed with double distilled water and dried overnight at $60{ }^{\circ} \mathrm{C}$. Free magnesium and carbonate apatite samples (Ap) were prepared as described above but in the absence of $\mathrm{Mg}^{2+}$ and $\mathrm{CO}_{3}{ }^{2-}$ sources in the solution. Dry powders of all samples were characterised in the as-prepared condition.

\subsection{Physico-chemical characterisation}

Calcium, phosphorus, magnesium and sodium concentrations of the unsintered powder samples were determined using inductively coupled plasma atomic emission spectroscopy (ICP), (Thermo Jarrel-Ash, Trace Scan Advantage). A $10 \mathrm{mg}$ quantity of the dried precipitates was dissolved in $17.5 \% \mathrm{HCl}$ and made up to $100 \mathrm{~mL}$ in a volumetric flask with double distilled water. The solutions were pumped through argon plasma excited by a $2 \mathrm{~kW} / 27.12 \mathrm{MHz}$ radiofrequency generator. The concentration of the elements present in the samples was determined by using their characteristic wavelengths $(\mathrm{Ca}$,

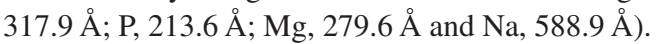

The carbonate content of the MCAp samples, evolved as $\mathrm{CO}_{2}$, was evaluated by thermogravimetric analysis (TGA) using a TA instruments SDT Q600. These analyses were performed by using $10 \mathrm{mg}$ of MCAp powders heated from $20-950{ }^{\circ} \mathrm{C}$ at a $20{ }^{\circ} \mathrm{C} / \mathrm{min}$ heating rate and at $100 \mathrm{~mL} / \mathrm{min}$ nitrogen flow rate. The first weight loss, from $25-160{ }^{\circ} \mathrm{C}$, corresponds to the release of adsorbed $\mathrm{H}_{2} \mathrm{O}$ on the surface of the crystals. In the second step $\left(160-400^{\circ} \mathrm{C}\right)$, the weight loss is due to the structural water. The weight loss in the third step $\left(400-950{ }^{\circ} \mathrm{C}\right)$ represents the decomposition of carbonate ion into $\mathrm{CO}_{2}^{5,16}$.

The absorption bands were characterised by Fourier-transform infrared spectroscopy (FTIR) (Nicolet Magna-IR 550 Spectrometer Series II), recorded in the range of $4000-400 \mathrm{~cm}^{-1}$. The samples pellets were prepared by mixing $10 \mathrm{mg}$ of the sample with $250 \mathrm{mg} \mathrm{KBr}$ (IR grade). The pellets were pressed at $10,000 \mathrm{psi}$ using a hydraulic press (Carver laboratory press, mode C, ser. $\mathrm{N}^{\circ}$. 33000-577, Fred S. Carver, Inc.).
The crystalline phases present in the Ap and MCAp unsintered powders were identified by X-ray diffraction analysis (XRD) using a Philips X'Pert diffractometer, with a curved crystal monochromator and $\mathrm{Cu} \mathrm{K} \alpha$ radiation $(45 \mathrm{kV}$, $45 \mathrm{~mA})$. Data were acquired from $10-60^{\circ}(2 \theta)$, at a step size of $0.02^{\circ}(2 \theta)$ and $3 \mathrm{~s}$ per step. The lattice parameters of the samples were calculated by using the correlation between interplanar distances and the Miller indices of reflecting plane $h, k$ and $l^{[17]}$. The a-axis and c-axis dimensions were determined from [300] and [002] planes, respectively.

The morphological evaluation of the powder samples was made using scanning electron microscopy (SEM) on a JEOL JSM6460LV, working at $15 \mathrm{kV}$. The samples were mounted on aluminium stubs with carbon tape and sputtered with a thin gold layer to avoid electrical charging.

\subsection{Dissolution experiments}

Dissolution experiments were carried out by immersing $12.5 \mathrm{mg} \pm 0.05 \mathrm{mg}$ of each sample, sieved to particle sizes from $63-90 \mu \mathrm{m}$, in $25 \mathrm{~mL}$ of $0.1 \mathrm{M}$ potassium acetate buffer solution $\left(\mathrm{KC}_{2} \mathrm{H}_{3} \mathrm{O}_{2}\right), \mathrm{pH} 6$, maintained at $37^{\circ} \mathrm{C}$ and stirred at a constant speed (100 rpm). Release of the calcium ions with time was measured at $30 \mathrm{~s}$ intervals using a $\mathrm{Ca}$-ion selective electrode attached to a $\mathrm{pH}$ system (Metrohm $\mathrm{pH}$ module 867 ) and analysed using Tiamo 2.2 software (Metrohm AG, Switzerland). Duplicate analyses of each sample were made and the results were expressed as means \pm standard deviations and analysed by one-way analysis of variance (ANOVA). Statistical significance was set at $p<0.05$.

\section{Results and Discussion}

The chemical composition (in wt. (\%)) of the powders, as well as the $(\mathrm{Ca}+\mathrm{Mg}) / \mathrm{P}$ and $\mathrm{Mg} / \mathrm{Ca}$ molar ratios, are summarised in Table 1. The samples without carbonate presented a Ca/Pratio of 1.57 , comparable to calcium-deficient apatites obtained from aqueous precipitation ${ }^{1}$. With the carbonate incorporation, the $(\mathrm{Ca}+\mathrm{Mg}) / \mathrm{P}$ molar ratio increased to the range 1.68-1.81. The magnesium content in the MCAp samples was not significantly different and therefore did not contribute to the $(\mathrm{Ca}+\mathrm{Mg}) / \mathrm{P}$ molar ratio.

The results show that as the carbonate amount increased, so too did the $(\mathrm{Ca}+\mathrm{Mg}) / \mathrm{P}$ molar ratio. The decrease in the $\mathrm{Ca}$ and $\mathrm{P}$ concentration accomplished by the increase in the $\mathrm{Na}$ concentration are evidence for the $\mathrm{CO}_{3}{ }^{2-}-$ for- $\mathrm{PO}_{4}{ }^{3-}$, B-type substitution. The substitution of a trivalent anion, $\mathrm{PO}_{4}{ }^{3-}$, by a bivalent anion, $\mathrm{CO}_{3}{ }^{2-}$, facilitates the incorporation of a monovalent cation $\left(\mathrm{Na}^{+}\right)$in the place of a divalent cation $\mathrm{Ca}^{2+}$ to maintain the charge balance ${ }^{1,5,14}$. The source of the $\mathrm{Na}^{+}$ions could be the sodium carbonate and sodium phosphate reagents used in the reaction. The radius of the monovalent $\mathrm{Na}^{+}$ion $(0.97 \AA)$ is close to that of the divalent $\mathrm{Ca}^{2+}$ ion $(0.99 \AA)$, while the radius of the $\mathrm{Mg}^{2+}$ ion is smaller $(0.66 \AA)$. The similarity in the radius of $\mathrm{Na}^{+}$and $\mathrm{Ca}^{2+}$ ions facilitates the Na-for-Ca substitution without causing any major changes in the lattice parameters of the apatite ${ }^{1,5}$. The $\mathrm{Na}$ incorporation into the apatite lattice was limited to less than $1 \mathrm{wt} .(\%)$, in spite of an excess of this ion being present in the carbonate-free solution. However, in the presence of $\mathrm{CO}_{3}{ }^{2-}$ ions, the incorporation of $\mathrm{Na}^{+}$ions increased up to 2 wt. $(\%)$. 
Table 1. Chemical composition (wt. $(\%))$ and the $(\mathrm{Ca}+\mathrm{Mg}) / \mathrm{P}$ and $\mathrm{Mg} / \mathrm{Ca}$ molar ratios of produced samples.

\begin{tabular}{|c|c|c|c|c|c|c|c|}
\hline \multirow[b]{2}{*}{ Apatite type } & \multicolumn{7}{|c|}{ Compositions (wt. (\%)) } \\
\hline & Mg & $\mathrm{Ca}$ & $\mathbf{P}$ & $\mathbf{N a}$ & $\mathrm{CO}_{3}$ & $\begin{array}{l}(\mathrm{Ca}+\mathrm{Mg}) / \mathrm{P} \\
\text { molar ratio }\end{array}$ & $\begin{array}{c}\mathrm{Mg} / \mathrm{Ca} \\
\text { molar ratio }\end{array}$ \\
\hline Ap & $0.028 \pm 0.000$ & $38.47 \pm 0.07$ & $18.99 \pm 0.04$ & $0.242 \pm 0.075$ & negligible & $1.57 \pm 0.001$ & $0.0012 \pm 0.000$ \\
\hline$\underset{(3 \mathrm{Mg} / 0 \mathrm{C} / 1 \mathrm{P})}{\mathrm{A}}$ & $0.646 \pm 0.006$ & $38.09 \pm 0.06$ & $19.28 \pm 0.00$ & $0.551 \pm 0.025$ & negligible & $1.57 \pm 0.003$ & $0.028 \pm 0.003$ \\
\hline $\begin{array}{c}\mathrm{B} \\
(3 \mathrm{Mg} / 1 \mathrm{C} / 1 \mathrm{P})\end{array}$ & $0.783 \pm 0.005$ & $38.78 \pm 0.01$ & $18.48 \pm 0.16$ & $0.965 \pm 0.015$ & $3.14 \pm 0.04$ & $1.68 \pm 0.015$ & $0.033 \pm 0.003$ \\
\hline $\begin{array}{c}\mathrm{C} \\
(3 \mathrm{Mg} / 3 \mathrm{C} / 1 \mathrm{P})\end{array}$ & $0.826 \pm 0.003$ & $35.99 \pm 0.32$ & $16.53 \pm 0.06$ & $1.193 \pm 0.040$ & $4.74 \pm 0.33$ & $1.75 \pm 0.022$ & $0.038 \pm 0.001$ \\
\hline $\begin{array}{c}\mathrm{D} \\
(3 \mathrm{Mg} / 5 \mathrm{C} / 1 \mathrm{P})\end{array}$ & $0.787 \pm 0.000$ & $35.63 \pm 0.14$ & $15.81 \pm 0.04$ & $1.977 \pm 0.003$ & $6.83 \pm 0.29$ & $1.81 \pm 0.003$ & $0.036 \pm 0.000$ \\
\hline
\end{tabular}

Table 1 shows the carbonate concentration as determined by TGA analysis. The MCAps with relatively constant $\mathrm{Mg}$ content presented an increase in carbonate content with increasing $\mathrm{CO}_{3}{ }^{2-}$ concentration.

The FTIR spectra of the apatites prepared in the absence of $\mathrm{CO}_{3}{ }^{2-}$ ions in solution showed bands at $861 \mathrm{~cm}^{-1}$ attributed to $\mathrm{HPO}_{4}^{2-}\left(v_{3} \mathrm{P}-\mathrm{O}-\mathrm{H}\right)$ and a hydroxyl $\left(\mathrm{OH}^{-}\right)$absorption band located at $637 \mathrm{~cm}^{-1}$ (Figure 1 - Ap and A). Calcium-deficient apatite can be partially attributed to the presence of $\mathrm{HPO}_{4}{ }^{2-}$ ions, which may be adsorbed onto the apatite surface or substitute for the $\mathrm{PO}_{4}{ }^{3-}$ site ${ }^{1}$. The intensity of this band decreased as the $\mathrm{CO}_{3}{ }^{2-}$ content increased.

The incorporation of $\mathrm{CO}_{3}^{2-}$ in the apatite lattice of the unsintered samples was confirmed by FTIR analyses (Figure 1 - B, C and D). The increase in the intensity of the $\mathrm{CO}_{3}{ }^{2-}$ absorption bands at $1416 \mathrm{~cm}^{-1}, 1474 \mathrm{~cm}^{-1}\left(\mathrm{v}_{3} \mathrm{C}-\mathrm{O}\right)$, and $873 \mathrm{~cm}^{-1}\left(\mathrm{v}_{2} \mathrm{C}-\mathrm{O}\right)$, is due to an increase in the amount of carbonate incorporated in the apatite lattice. The decrease in the intensity of the $\mathrm{PO}_{4}^{3-}$ absorption bands with increasing carbonate content confirms the B-type carbonate substitution in the MCAp powders ${ }^{1,5}$. The increase in the carbonate content also resulted in the disappearance of the $\mathrm{PO}_{4}{ }^{3-}$ band at $474 \mathrm{~cm}^{-1}\left(\mathrm{v}_{2} \mathrm{P}-\mathrm{O}\right)$, and in the loss of the resolution of the $\mathrm{PO}_{4}^{3-}$ absorption bands at 1030 and $1098 \mathrm{~cm}^{-1}\left(\mathrm{v}_{3} \mathrm{P}-\mathrm{O}\right)$.

The incorporation of magnesium and carbonate destabilises the apatite lattice, causing broadening of the $\mathrm{PO}_{4}{ }^{3-}$ bands in the stretching regions $\left(1030 \mathrm{~cm}^{-1}\right)$, the bending $\left(565 \mathrm{~cm}^{-1}\right)$ vibration mode and decreasing the intensity of the $v_{4} \mathrm{PO}_{4}^{3-}$ band.

The decrease in crystallinity is indicated by a loss in the resolution and in the broadening of the phosphate absorption bands $\left(\mathrm{v}_{3} \mathrm{P}-\mathrm{O}\right)$ (Figure $1-\mathrm{B}, \mathrm{C}$ and $\left.\mathrm{D}\right)$. Higher resolution of the $\mathrm{v}_{4} \mathrm{P}-\mathrm{O}$ bands indicates higher crystallinity (larger crystal size and/or less strain) in the MCAp (Figure 1 - A) ${ }^{1,5}$.

Figure 2 shows the increasing ratio of the $\left[\left(v_{3} \mathrm{CO}_{3}{ }^{2-}\right) /\left(v_{4} \mathrm{PO}_{4}^{3-}\right)\right]$ absorption bands with increasing carbonate contents in the MCAp unsintered powders. The increase of the ratio value confirmed a B-type carbonate substitution.

In concordance with the FTIR results, the XRD pattern (Figure 3) showed a slight broadening of the apatite diffraction peaks for the MCAp samples with higher $\mathrm{CO}_{3}{ }^{2-}$ contents, suggesting a decrease in crystallinity, and reflecting a reduction in crystal size or increase in strain ${ }^{1,17}$.

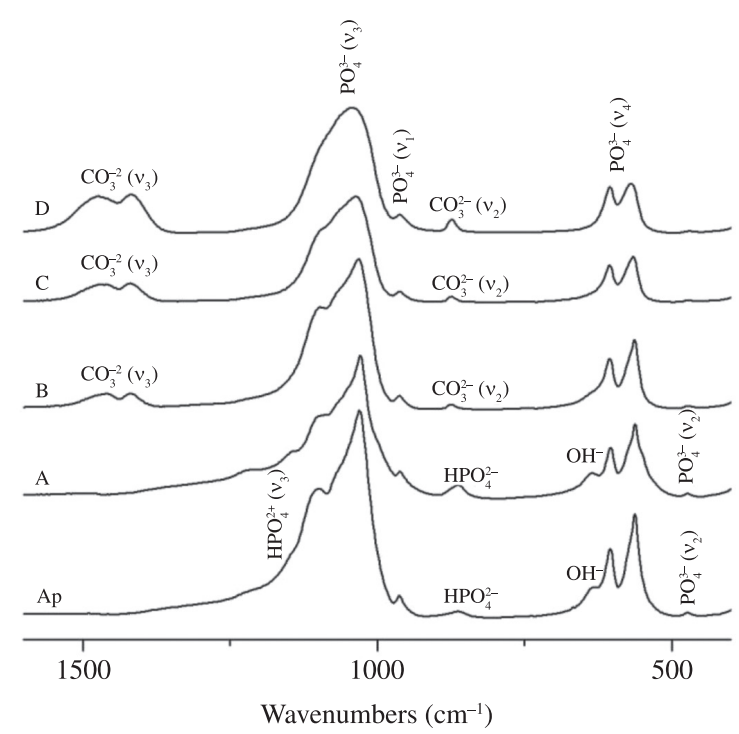

Figure 1. FTIR spectra (from 1500-500 $\mathrm{cm}^{-1}$ ) of Ap and MCAp powders with similar $\mathrm{Mg} / \mathrm{Ca}$ molar ratio and different $\mathrm{CO}_{3}{ }^{2-}$ contents; $3 \mathrm{Mg} / 0 \mathrm{C} / 1 \mathrm{P}$ (A), $3 \mathrm{Mg} / 1 \mathrm{C} / 1 \mathrm{P}$ (B), $3 \mathrm{Mg} / 3 \mathrm{C} / 1 \mathrm{P}$ (C) and $3 \mathrm{Mg} / 5 \mathrm{C} / 1 \mathrm{P}(\mathrm{D})$.

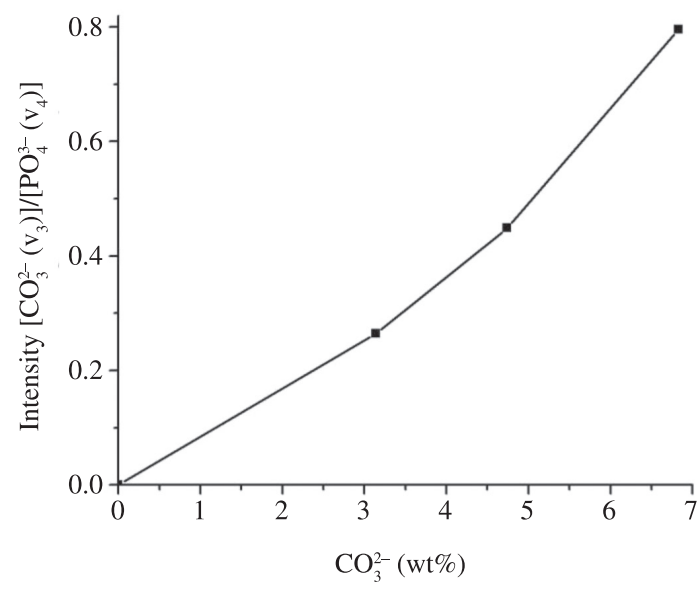

Figure 2. Graph showing increasing ratio of the $\mathrm{CO}_{3}{ }^{2-}$ and $\mathrm{PO}_{4}{ }^{3-}$ absorption bands with increasing carbonate content of the unsintered MCAp powders. 


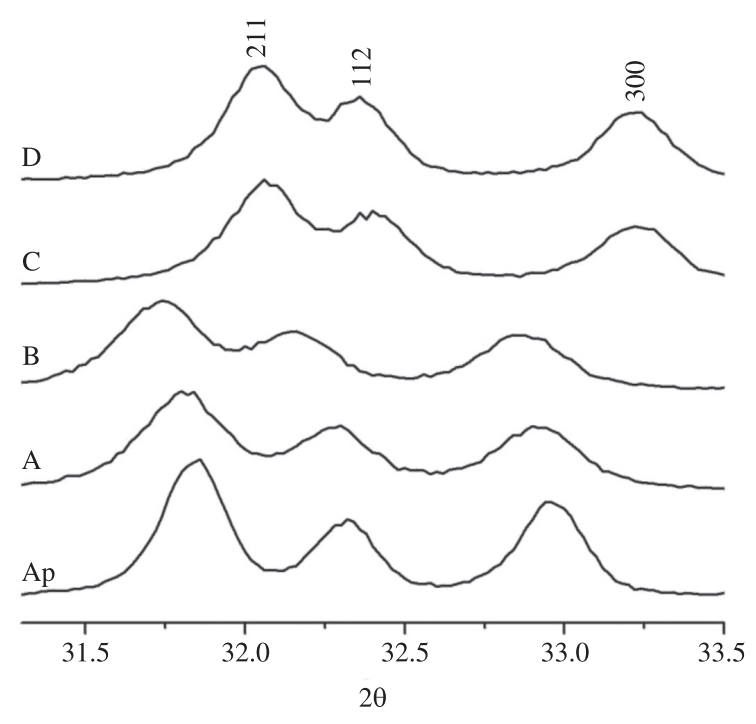

Figure 3. XRD pattern (from 31.5 to $33.5^{\circ}$ ) of Ap and MCAp powders with similar $\mathrm{Mg} / \mathrm{Ca}$ molar ratios and different $\mathrm{CO}_{3}{ }^{2-}$ content; $3 \mathrm{Mg} / 0 \mathrm{C} / 1 \mathrm{P}(\mathrm{A}), 3 \mathrm{Mg} / 1 \mathrm{C} / 1 \mathrm{P}$ (B), $3 \mathrm{Mg} / 3 \mathrm{C} / 1 \mathrm{P}$ (C) and $3 \mathrm{Mg} / 5 \mathrm{C} / 1 \mathrm{P}$ (D).

A shift in the diffraction peaks (211 and 300) to a higher $2 \theta$ angle with increasing $\mathrm{CO}_{3}{ }^{2-}$ content in the MCAp samples indicates decreasing a-axis dimensions. The contraction in the a-axis dimensions (compared to that of the magnesium- and carbonate-free apatites) can be attributed to the combined partial substitution of $\mathrm{Mg}^{2+}-$ for $-\mathrm{Ca}^{2+1,16}$ and $\mathrm{CO}_{3}{ }^{2-}$-for- $\mathrm{PO}_{4}{ }^{3-1,14}$. The shorter O-O distance in the $\mathrm{CO}_{3}{ }^{2-}$ group, when compared to that in the tetrahedral $\mathrm{PO}_{4}^{3-}$ group, and the substitution of smaller planar $\mathrm{CO}_{3}{ }^{2-}$ groups for the larger tetrahedral $\mathrm{PO}_{4}^{3-}$ group, contribute to these effects on the lattice parameters ${ }^{1,14}$. Some authors related that the incorporation of $\mathrm{Mg}^{2+}$ and $\mathrm{CO}_{3}{ }^{2-}$ in the apatite lattice causes a reduction of crystal size, contraction in the a-axis dimension and expansion in the c-axis dimension, as well as increased solubility when compared to carbonate-free apatites ${ }^{9,18,19}$.

The combined effects on the lattice parameters (a- and c-axis dimensions) of the simultaneous substitution of $\mathrm{Mg}^{2+}$ and $\mathrm{CO}_{3}^{2-}$ in the apatite can be seen in Figure 4.

The crystal morphology of the magnesium- and carbonate-free synthetic apatite is shown in Figure 5. Incorporation of magnesium caused a significant decrease in crystal size (Figure 6a), and the combined incorporation of magnesium and carbonate caused a further decrease in crystal size and change in crystal shape (Figure 6b-d). The crystal shape changed from large needle-like crystals (Figure 6a, b) to considerably smaller rods (Figure 6c, d) as the $\mathrm{a} / \mathrm{c}$ ratio decreases.

The $\mathrm{Ca}$ ion release in acidic buffer from synthethic MCAp is shown in Figure 7. All solutions reached calcium saturation within 60 minutes.

The amount of $\mathrm{Ca}^{2+}$ ions released in 60 minutes from apatites containing $\mathrm{Mg}^{2+}$ ions and free of carbonate $(3 \mathrm{Mg} / 0 \mathrm{C} / 1 \mathrm{P})$ and the MCAp with lower $\mathrm{CO}_{3}{ }^{2-}$ content $(3 \mathrm{Mg} / 1 \mathrm{C} / 1 \mathrm{P})$ was not significantly different.

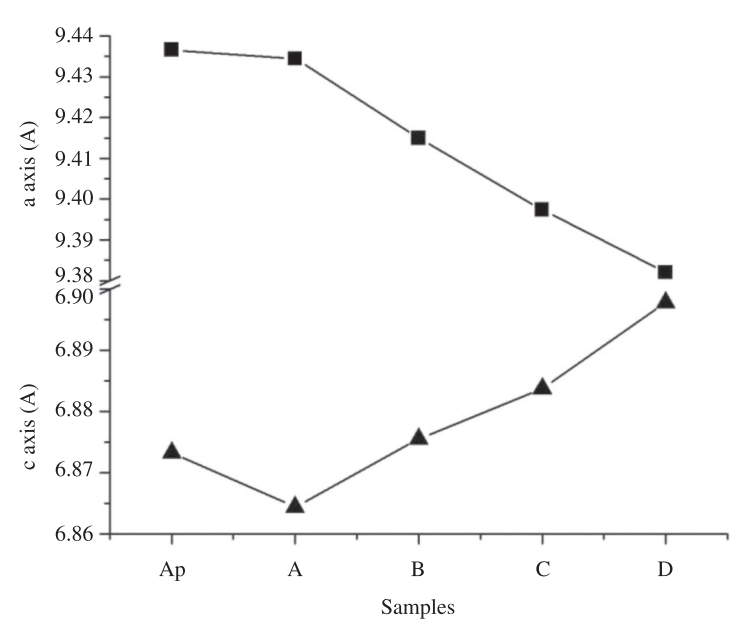

Figure 4. Graph showing the combined effects on the lattice parameters (a- and c-axis dimensions) of the simultaneous substitution of $\mathrm{Mg}^{2+}$ and $\mathrm{CO}_{3}{ }^{2-}$ in the apatite powders.

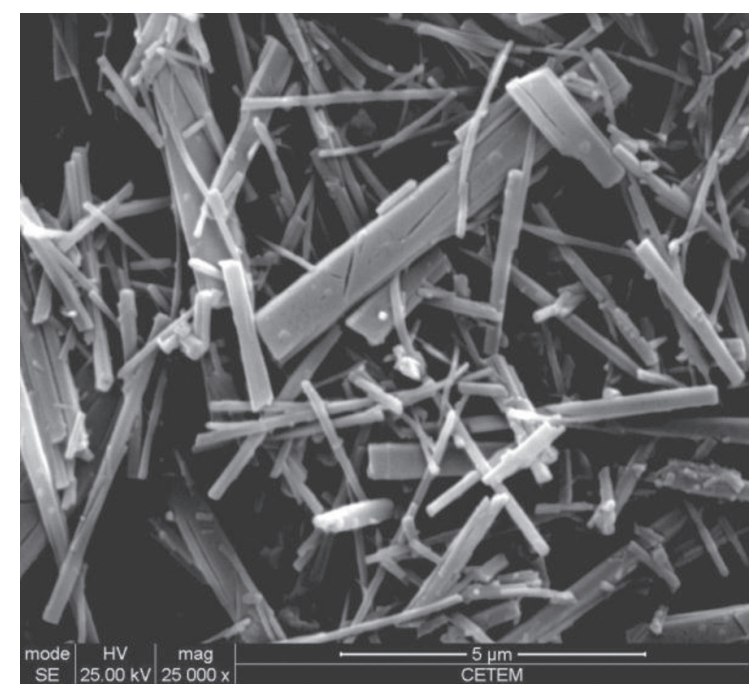

Figure 5. SEM images of magnesium- and carbonate-free apatite powder.

The amount of $\mathrm{Ca}$ ions released in the same period in acidic buffer from MCAp containing higher $\mathrm{CO}_{3}{ }^{2-}$ contents increased as carbonate content increased.

The incorporation of $\mathrm{CO}_{3}{ }^{2-}$ in the apatite lattice caused a decrease in the crystal shape, as seen in SEM images showing significant differences in the specific area which contributed to the release of $\mathrm{Ca}^{2+}$ in the dissolution kinetics.

The separate and combined effects of carbonate and magnesium on increasing the solubility of apatites are consistent with earlier reports ${ }^{1,9,20,21}$. Since the magnesium concentration is similar in the MCAp samples, the increase in dissolution rate is due only to an increase in the carbonate incorporation in these samples. This behaviour was also observed in A-type carbonate apatites $\left(\mathrm{CO}_{3}{ }^{2-}-\text { for- }-\mathrm{OH}^{-}\right)^{20}$.

Carbonate apatites present higher solubility when compared to carbonate-free apatite due to the fact that $\mathrm{Ca}-\mathrm{PO}_{4}$ bonds are stronger than $\mathrm{Ca}-\mathrm{CO}_{3}$ bonds, making the carbonate apatite more susceptible to acid dissolution ${ }^{2}$. 


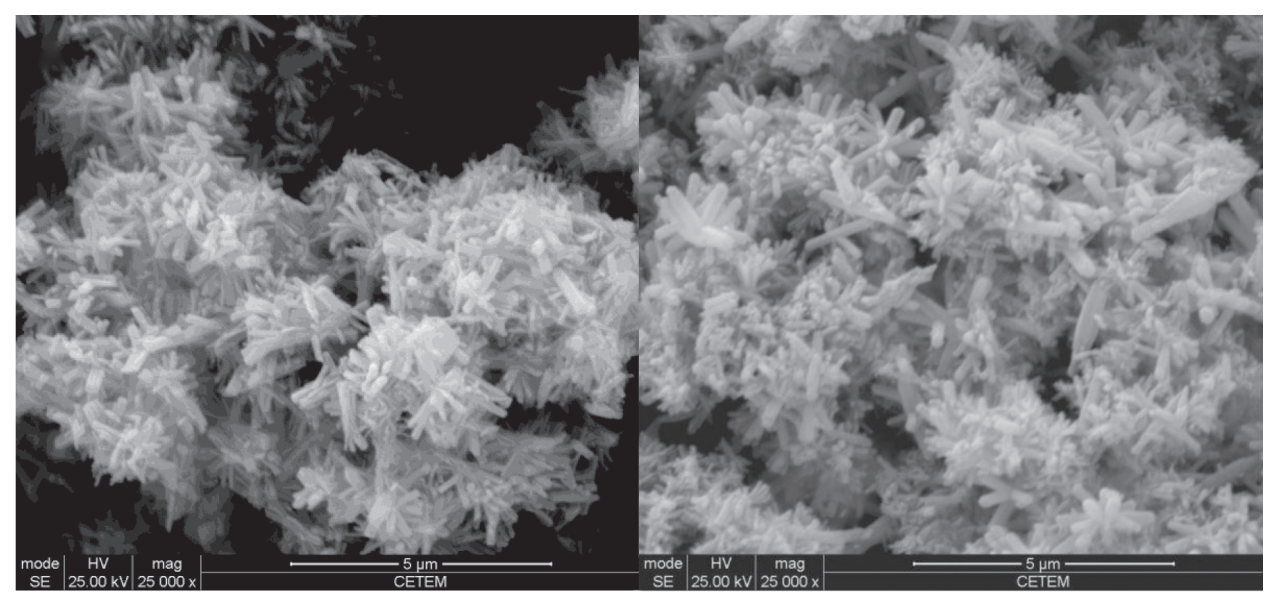

(a)

(b)

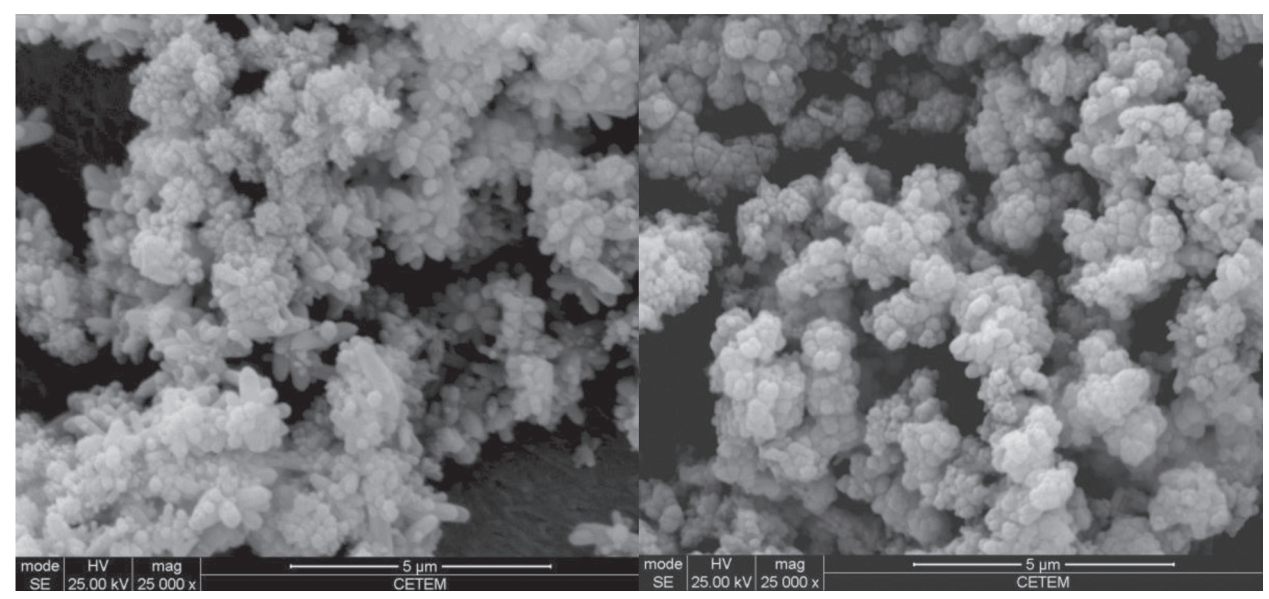

(c)

(d)

Figure 6. SEM images of the of MCAp powders with similar $\mathrm{Mg} / \mathrm{Ca}$ molar ratios and different $\mathrm{CO}_{3}{ }^{2-}$ content; $3 \mathrm{Mg} / \mathrm{OC} / 1 \mathrm{P}(\mathrm{a}), 3 \mathrm{Mg} / 1 \mathrm{C} / 1 \mathrm{P}$ (b), $3 \mathrm{Mg} / 3 \mathrm{C} / 1 \mathrm{P}(\mathrm{c})$ and $3 \mathrm{Mg} / 5 \mathrm{C} / 1 \mathrm{P}(\mathrm{d})$.

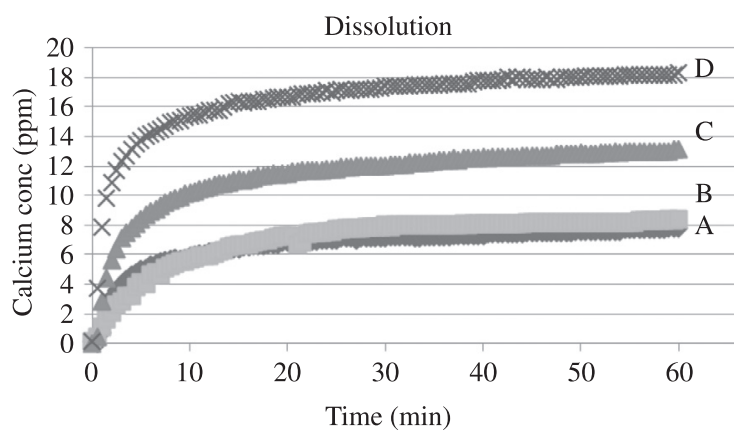

Figure 7. The amount of $\mathrm{Ca}$ ions released after 60 minutes in acidic buffer solution from MCAp samples with similar $\mathrm{Mg} / \mathrm{Ca}$ molar ratios and different $\mathrm{CO}_{3}{ }^{2-}$ content; $3 \mathrm{Mg} / 0 \mathrm{C} / 1 \mathrm{P}(\mathrm{A}), 3 \mathrm{Mg} / 1 \mathrm{C} / 1 \mathrm{P}$ (B), $3 \mathrm{Mg} / 3 \mathrm{C} / 1 \mathrm{P}(\mathrm{C})$ and $3 \mathrm{Mg} / 5 \mathrm{C} / 1 \mathrm{P}(\mathrm{D})$.

Magnesium and carbonate incorporation, individually or in combination, induce crystallinity reduction and a higher number of structural defects within the apatite lattice. The disorder caused by the ion substitutions within the crystal weakens the apatite bonds, which increases chemical reactivity. The increase in apatite solubility caused by carbonate incorporation is further increased when $\mathrm{Mg}^{2+}$ ions were also incorporated ${ }^{7-9,22,23}$.

\section{Conclusions}

The unsintered MCAp samples showed a B-type carbonate substitution $\left(\mathrm{CO}_{3}{ }^{2-}-\right.$ for- $\left.-\mathrm{PO}_{4}{ }^{3-}\right)$. The simultaneous incorporation of $\mathrm{Mg}^{2+}$ and $\mathrm{CO}_{3}{ }^{2-}$ ions in the MCAp samples combined the individual effects of these ions on the properties of apatite. In samples with similar $\mathrm{Mg} / \mathrm{Ca}$ molar ratio, increasing the carbonate content resulted in a decrease in crystallite size and an increase in the release of calcium in a $\mathrm{pH} 6$ solution.

\section{Acknowledgments}

This study was supported by research grant no. AR056208 from the NIAMS/NIH (LeGeros) and by FAPERJ, CNPq and CAPES (Dr. Soares). The authors are grateful for the professional collaboration of Dr. Dindo Mijares of NYU College of Dentistry. 


\section{References}

1. LeGeros RZ. Calcium phosphates in oral biology and medicine. In: LeGeros RZ. Monographs in Oral Sciences. H.M. Myers, Basel; 1991. v. 15, p. 37-58.

2. Wopenka B and Pasteris JD. A mineralogical perspective on the apatite in bone. Materials Science and Engineering: C. $2005 ; 25: 131-143$. http://dx.doi.org/10.1016/j. msec.2005.01.008

3. Porter A, Patel N, Brooks R, Best S, Rushton N and Bonfield W. Effect of carbonate substitution on the ultrastructural characteristics of hydroxyapatite implants. Journal of Materials Science: Materials in Medicine. 2005; 16:899-907. http:// dx.doi.org/10.1007/s10856-005-4424-1

4. Inoue M, LeGeros RZ, Hidetsugu T, Nagatsuka H, Tamamoto $\mathrm{T}$ and Nagia N. In vitro response of osteoblast-like and odontoblast-like cells to unsubtituted and substituted apatites. Journal of Biomedical Materials Research. 2004; 70A:585593. http://dx.doi.org/10.1002/jbm.a.30116

5. Yao F, LeGeros JP and LeGeros RZ. Simultaneous incorporation of carbonate and fluoride in synthetic apatites: Effect on crystallographic and physic-chemical properties. Acta Biomaterialia. 2009; 5:2169-2177. http://dx.doi.org/10.1016/j. actbio.2009.02.007

6. Ren F, Leng Y, Xin R and Ge X. Synthesis, characterization and ab initio simulation of magnesium-substituted hydroxyapatite. Acta Biomaterialia. 2010; 6:2787-2796. http://dx.doi. org/10.1016/j.actbio.2009.12.044

7. LeGeros RZ, Kijkowska R, Bautista C and LeGeros JP. Synergistic effects of magnesium and carbonate on properties of biological and synthetic apatites. Connective Tissue Research. 1995; 33:203-209. http://dx.doi. org/10.3109/03008209509017003

8. LeGeros RZ, Sakae T, Bautista C, Retino M and LeGeros JP. Magnesium and carbonate in enamel and synthetic apatites. Advances in Dental Research. 1996; 10:225-31. http://dx.doi. org/10.1177/08959374960100021801

9. Dorozhkin SV. Calcium orthophosphates: Occurrence, properties, biomineralization, pathological calcification and biomimetic applications. Biomatter. 2011; 1-2:121-164. http:// dx.doi.org/10.4161/biom. 18790

10. Araújo JC, Sader MS, Moreira EL, Moraes VCA, LeGeros $\mathrm{RZ}$ and Soares GA. Maximum substitution of magnesium for calcium sites in Mg- $\beta$-TCP structure determined by $\mathrm{X}$-ray powder diffraction with Rietveld refinement. Materials Chemistry and Physics. 2009; 118:337-340. http://dx.doi. org/10.1016/j.matchemphys.2009.07.064

11. Laurencin D, Almora-Barrios N, De Leeuw NH, Gervais C, Bonhomme C, Mauri F et al. Magnesium incorporation into hydroxyapatite. Biomaterials. 2011; 32:1826-1837. http:// dx.doi.org/10.1016/j.biomaterials.2010.11.017

12. Bonel G. Contribution à l'étude de la carbonation des apatites. Annali di Chimica. 1972; 7:65-88.
13. Elliott JC, Holcomb DW and Young RA. Infrared determination of the degree of substitution of hydroxyl by carbonate ions in human dental enamel. Calcified Tissue International. 1985; 37:372-375. http://dx.doi.org/10.1007/ BF02553704

14. Kannan S, Vieira SI, Olhero SM, Torres PMC, Pina S, Da Cruz e Silva OAB et al. Synthesis, mechanical and biological characterization of ionic doped carbonated hydroxyapatite/ $\beta$-tricalcium phosphate mixtures. Acta Biomaterialia 2011; 7:1835-1843. http://dx.doi.org/10.1016/j. actbio.2010.12.009

15. Zou C, Cheng K, Weng W, Song C, Du P, Shen G et al. Characterization and dissolution-reprecipitation behavior of biphasic tricalcium phosphate powders. Journal of Alloys and Compounds. 2011; 509:6852-6858. http://dx.doi.org/10.1016/j. jallcom.2011.03.158

16. Klug HP and Alexander LE. X-ray Diffraction Procedures of Polycrystalline and Amorphous Materials. 2nd ed. New York: Willey; 1974.

17. Tônsuaadu K, Peld M and Leskelã T. A thermoanalytical study of synthetic carbonate-containing apatites. Thermochimica Acta. 1995; 256:55-65. http://dx.doi.org/10.1016/00406031(94)02169-O

18. Okazaki M and LeGeros RZ, Crystallographic and chemical properties of $\mathrm{Mg}$-containing apatites before and after suspension in solutions. Magnesium Research. 1992; 5:103108.

19. Landi E, Tampieri A, Belmonte MM, Celotti G, Sandri $\mathrm{M}$, Gigante $\mathrm{A}$ et al. Biomimetic $\mathrm{Mg}-$ and $\mathrm{Mg}, \mathrm{CO}_{3}-$ substituted hydroxyapatites: Synthesis, characterization and in vitro behavior. Journal of the European Ceramic Society. 2005; 26:2593-2601. http://dx.doi.org/10.1016/j. jeurceramsoc.2005.06.040

20. Zyman ZZ, Rokhmistrov DV, Glushko VI and Ivanov IG. Thermal impurity reactions and structural changes in slightly carbonated hydroxyapatite. Journal of Materials Science: Materials in Medicine. 2009; 20:1389-1399. http://dx.doi. org/10.1007/s10856-009-3706-4

21. Gibson IR and Bonfield W. Novel synthesis and characterization of an AB-type carbonate-substituted hydroxyapatite. Journal of Biomedical Materials Research. 2002; 59:697-708. http:// dx.doi.org/10.1002/jbm.10044

22. Liao S, Watari F, Xu G, Nigiam M, Ramakrishna S and Chan CK. Morphological effects of variant carbonates in biomimetic hydroxyapatite. Materials Letters. 2007; 61:3624-3628. http:// dx.doi.org/10.1016/j.matlet.2006.12.007

23. LeGeros RZ, Ito A, Ishikawa K, Sakae T and LeGeros JP. Fundamentals of Hydroxyapatite and Related Calcium Phosphates. In: Basu B, Katti DS and Kumar A. Advanced Biomaterials: Fundamentals, Processing, and Applications. New York: Wiley; 2009. http://dx.doi.org/10.1002/9780470891315. ch2 